\title{
Description of Illustrations
}

King Jayavarman vil in meditation (frontispiece). The reign of Jayavarman VII (1181-1218 A.D.) marks an increase of Buddhist influence in the Khmer empire of Cambodia. Inscriptions of that period stress Buddhist virtues such as charity, nonviolence and compassion toward the entire world. The Ta Prohm inscription of Jayavarman VII relates to the establishment of a great institution of learning, providing board and lodging for 439 professors and 970 scholars studying with them (see Staal 1970 ). Jayavarman VII adapted the traditional cult of divine kingship to his Buddhist faith, and many statues portray him as the bodhisattva Lokeśvara. As the Bayon style, which is typical of his reign, develops, the sculptures, which often represent the king in meditation, increasingly seem to portray a real person (see Coedès 1967, 108109).-Khmer, sandstone, Museum Phnom Penh.

ŚRI YANTRA or ŚRİ CaKRA (on title page). This is an object for meditation. It may be built from a variety of materials, engraved on a metal plate, drawn on a piece of paper or on the floor in front of the yogin. It is constructed from triangles, some with the base toward him (vahni "fire"), the others with the base away from him (sakti "power"). The former are connected with male deities like siva, the latter with female deities like Pārvatĩ. The nine triangles, which together form 43 small triangles, are surrounded by eight lotus petals, then sixteen lotus petals, circles, and a pattern of straight lines (called bhüpura). The construction of the yantra starts in the middle: the sides of the small triangles are meticulously produced. Such diagrams are also constructed at the outset of many rituals. Meditation on the yantra starts from the outer lines and proceeds to the center. (See Zimmer 1926, plate 36; Pott 1966, figure 7; Avalon 1948, and other works of Avalon or Sir John Woodroffe.) 


\section{PLATES}

Following page 74

1. VișNu ASLEEP betWeEN CREations. At the end of each world period, when society has fully disintegrated, all traces of truth and goodness are lost, and sages and saints are no longer found, the creator Viṣnu reabsorbs the universe. First Vișnu becomes the sun and his scorching rays turn the world into dust. Then, as fire, he burns the earth. Finally, as rain, he floods the earth, which dissolves into the cosmic ocean together with the sun, the moon and the stars. In that ocean Viṣnu sleeps, alone and unperceived, until through meditation he manifests a new creation (see Zimmer 1946, pp. 35-53).-Khmer, limestone, early twelfth century (Rijksmuseum, Amsterdam).

2. The force of tapas: Descent of the Ganges. At a time of excessive drought and widespread famine, when there was not enough water even to perform the ancestral rites, the royal sage Bhagiratha attempts to move the Gods into releasing the river Ganges which flows in heaven. For a thousand years he performs ascetic exercises and builds up ascetic energy (tapas), keeping his arms constantly raised and frying himself sitting under the midday sun and between four fires. Impressed by his tapas, God Brahmā appears and hears his request. But Brahmā opines that the release of the Ganges would cause such ferocious downpours of water, that the earth would be split. Only Siva is strong enough to withstand such force. So Bhagiratha goes to the Himalayas and engages upon a second round of tapas, standing on one foot with his arms raised and living on water and air. At last Siva responds and grants his request: the waters come pouring down. With his head siva catches the mighty stream and causes the water to meander through the labyrinth of his long matted hair. Thus the river Ganges descends from the Himalayas (see Zimmer 1946, pp. 109-121).-The large relief at Māmallapuram near Madras (Pallava, early seventh century A.D.) depicts these events (though another interpretation is possible: Krishnaswami Aiyangar 1917). At the bottom, Bhagiratha does penance at Gokarna; on the right a pig, beneath the tusk, imitates him. Above, he intensifies his tapas until Siva appears with his retinue of forest dwarfs. Through the vertical cleft the Ganges pours down, its presence marked by serpentine water goddesses.-Photograph by Robert Gardner, Cambridge.

3. SIVA, THE DIVINE YOGIN. Siva as wandering ascetic (bhikșātana$m \bar{u} r t i)$, a drum in his right upper hand and a begging bowl, made from a human skull, in his left lower hand. His headgear and the matted hair of the ascetic are adorned with a skull, a cobra, a crescent moon, and are studded with the flowers of the hallucinogenic Dātura plant. His 
third eye clearly visible, he wears a male and a female earring, and another cobra around his waist. A young deer tries to reach the fingers of his lower right hand.-Early Chola bronze, from 1048 A.D., Tiruveñgādu, Tanjore District, South India (now in the Madras Government Museum; a different photograph in Sivaramamurti 1963, plate 87).

4. ŚIVA's DANCE OF DESTRUCTION (gajasamhāramürti). When evil assumes the shape of a wild elephant, Siva compels the dangerous monster to dance, and goes on until his victim falls dead. He flays him, and with the two uppermost hands of his eight arms, stretches the skin. The next two hands carry an elephant's hook and a noose. The next pair a drum and the elephant's tusk. The lower hands carry the trident and an alms bowl made of a skull, Siva's attributes as a wandering ascetic.-Recent South Indian bronze from a private collection.

5. SIVA, THE DIVINE PRECEPTOR (vyäkhyāna-dakşinämürti). Siva as guru is called daksinanmürti because he faces south $(d a k s i n a \bar{a})$. He faces south since the traditional teachings come from the north. His images occur on the southern outer walls of the four gateways (gopura) of each of the great South Indian temples. There are three forms: $j \tilde{n} \bar{a} n a-d a k s i n \bar{a} m \bar{u} r t i$, yoga-dakșināmūrti and vyākhyana-dakșināmūrti. In the form depicted here Siva expounds a commentary (vyäkhyāna) and holds a book in his left hand, while he expounds knowledge with his right. The rear right hand holds a rosary, with a snake curling above it; the left hand holds fire. Behind him stands a stylized tree. The audience consists of a bull and several bearded sages. Under his foot lies the dwarf demon "forgetfulness," which is also trampled by Siva as Natarāja "king of the dance."-Stone sculpture from the eastern gateway of the Chidambaram temple, late Chola (photograph by J. C. Harle, also published in Harle 1963, plate 109).

6. Karman: Ritual activity in a Vedic SACRIfice. While karman has come to denote any activity, it referred originally to Vedic ritual. These Vedic rituals originated in their present form more than two and a half thousand years ago; they are still being performed, albeit rarely and in a few inaccessible places. Here South Indian brahmans perform such a ceremony in Tanjore District, Madras State. The Yajurveda priest in the foreground makes an oblation into the fire. The priest behind him chants the Sāmaveda with folded hands.-From a collection of photographs presented to the author by one of the participating priests.

7. Prapatti: Surrender to God. The philosopher Rāmānuja (born A.D. 1018), founder of the philosophic system Visiststadvaita ("non-dualism of the qualified absolute") which stresses loving devotion and surrender to a personal God. This is the traditional representation of 
Rāmānuja, as a brahman with a sacred thread, with Viṣnu's symbols on his forehead, the staff of a wandering ascetic (samnyäsin) and his hands folded in devotion.-Recent South Indian bronze from a private collection.

8. Prajñã: Spiritual wisdom. The Buddhist mystical notion of prajñ $\bar{a}$ corresponds to a large extent to the notion of $j \tilde{n} \bar{a} n a$ found in the Upanișads and the Vedanta. The Buddha is here portrayed with the traditional protruberance on his head (usnisa) and with a circle of white hair ( $\bar{u} r n \bar{a})$ between the eyebrows. These have been related to the turbans and jewels, respectively, found on earlier statues (Lamotte $195^{8}$, p. 739). In accordance with canonic texts, curls on the Buddha's head and the $\bar{u} r n \bar{a}$ turn clockwise (pradakșināuartakeśa).-Buddha head from Plaosan, Central Java, ninth century A.D. (Rijksmuseum voor Volkenkunde, Leiden).

Following page ${ }_{3} 8$

9. Bhakti: Loving devotion (The saint Sundaramūrti). Sundaramürti (eighth century A.D.) was "born of poor Brahmin parents but his beauty as a child was such that he attracted the attention of the local chieftain Narasinga Munaiyadaraiyan who, with the consent of the parents, brought him up. When his marriage with a girl of his own caste was about to take place it was stopped by the mysterious intervention of Siva who claimed him as his slave. A little later Sundara fell in love with two women, one a dancing girl of Tiruvālür and the other a s'üdra girl of Tiruvorriyūr. Their jealousies, it is said, could only be resolved by Siva himself acting as a messenger to one of them. . . . Sundara is also credited with many miracles and the contemporary Chera ruler, Cheramān Perumāl, was his friend. They visited each other regularly and made their last journey to the abode of Siva in Mount Kailāsa together, Sundara on a white elephant and Cheramān Perumāl on a horse. Sundara's devotion to Siva was that of an intimate friend so that he was given the title Tambirān-Tōlan ('Friend of God')" (Nilakanta Sastri 1955, p. 407).-Chola bronze, thirteenth century (collection James D. Baldwin, Fairview, Pennsylvania).

10a. Horned deity with animals from Harappā. This famous Harappā seal, made of the soft stone called steatite and possibly 4,000 years old, represents a horned deity surrounded by animals. This personage, also depicted on two other seals, has buffalo horns and is adorned with bangles and what appear to be necklaces. Ithyphallic, cross-legged and possibly three-faced, he is here surrounded by a rhinoceros, a buffalo, an elephant and a tiger. Beneath his stool are two antelopes or goats, which have been compared to the deer in representations of the Buddha 
preaching his first sermon in the Deer-park at Banaras (Basham 1954, p. 29). Sir John Marshall called this God "Proto-Siva"; Siva, after all, is sometimes called Paśupati "Lord of Beasts." The figure has often been considered a yogin, but without much justification.

10b. The six cakras in Kuṇpalinĩ Yoga. The six cakras or nerve centers through which the kundalini rises during yogic meditation, correspond to specific regions of the spinal column (here drawn on the left) and to specific deities and their consorts (here drawn on the right): mūlädhära (between anus and genitals) to Ganapati, svädhișthāna (above genitals) to Brahmā, maṇipūra (around the navel) to Viṣnu, anāhata (around the heart) to Rudra, viśuddha (around the throat) to Maheśvara, and $\bar{a} j \tilde{j} \tilde{a} \bar{a}$ (between the eyebrows) to Sadāsiva. The corresponding mantras are: Lang, Vang, Rang, Yang, Hang and Om (cf. Pott 1966, which discusses also Buddhist parallels).-Ink and color on paper, Tanjore, nineteenth century (collection Ajit Mookerjee, now in the Tantra Museum, London; also reproduced in Rawson 1973, plate 55).

11a. Yantra or manpala: aerial view of Borobudur on Java. The yantra diagrams or mandala circles which are constructed for meditation and at the outset of many rituals, well known from Tibetan scrolls, also occur in the groundplans of many temples and religious monuments in the countries where Indian civilization has spread. The groundplan of Borobudur (Central Java, ninth century), here seen from the air, enables pilgrims to perform a circumambulatory meditation, starting from the outer terraces which depict scenes from the life of the Buddha and proceeding inward towards the Buddha statues inside the numerous circular stūpas.-Prusahaan National Aerial Survey, Jakarta; Fontein, Soekmono and Suleiman 1971, plate 8.

11 b. Ritual preparation of a maṇala. Many religious ceremonies begin with a consecration in the form of a mandala prepared on the floor. Here a preparatory rite for a buffalo sacrifice is the drawing of a mandala by Brahmins in the Himalayan village of Sirkanda, Garhwal District, Uttar Pradesh.-Photograph by G. D. Berreman, Berkeley; cf. Berreman 1972, P. 391.

12. Muhammad's heavenly ascent. A verse of the Koran (17:1): "Glory to him who made his servant go from the mosque al-Harām to the mosque al-Akṣā" refers to Muhammad's nocturnal trip from the $\mathrm{Ka}^{\mathrm{c}} \mathrm{ba}$ in Mecca to a mosque either in Jerusalem or in heaven. This journey (isra $\left.\bar{a}^{\prime}\right)$ is generally interpreted as a mystic ascent to heaven $\left(m i^{i} r \bar{a} j\right)$. The prophet, his face veiled to prevent the direct vision of God, is seated on Burāk, a mare with a woman's face, guided by Gabriel and surrounded by other angels. The mystical character of this journey 
is corroborated by later traditions. One of these relates how Muhammad, after 70,000 conversations with God, returned to find his bed still warm and the water from a jug, kicked over when he hurriedly left, not yet fully spilt (Wensinck and Kramers 1941, pp. 227-228, 509-511).Persian miniature painting, sixteenth century, from a manuscript of a work by the poet Nizāmi entitled Makhzan al-asrār "The treasury of mysteries" (Patris 1948, p. 51).

13. Chuang Tzu's dream of the Butterfly. "Once Chuang-tzu dreamed that he was a butterfly, a butterfly gaily fluttering (was he showing himself what it would please him to be?), and did not know that he was Chuang-tzu. Suddenly he awoke, and all at once he was Chuangtzu. He does not know whether he is Chuang-tzu who dreamed that he was a butterfly or a butterfly dreaming that he is Chuang-tzu. Between Chuang-tzu and the butterfly certainly there was a dividing; this is all that is meant by the transformations of things" (from the second chapter of Chuang Tzu's work: Graham 1969, p. 159; see also Watson 1964, p. 45).-A painting by the Japanese artist Nakayama Kōyo (1717-1780) of the Nanga school (see Cahill 1972, pp. 11, 24). In a private collection, Japan.

14a. Kalmu in 1958 wirh his GOAT HeRd. Kalmu, son of a blacksmith, in the Himalayan village of Sirkanda, Garhwal District, Uttar Pradesh. Kalma was then thirteen years old, a third-grade dropout from the village school, "uninterested in learning from his father his hereditary trade" and "not particularly interested in or challenged by life" (Berreman 1972, p. $3^{81}$ ), but perchance photographed by Berreman (1972, plate 32). Note that according to Chadwick, because of "solitude and quiet," "a large proportion of seers have been drawn from the shepherd class all over Europe and Asia" (Chadwick 1942, p. 59). They are the precursors of the "wanderers" (parivräjaka) of the ascetic tradition.

14b. Kalmu in 1968 as Devatā (God) IN FRont of his temple. When Berreman visited Sirkanda again in 1968 , Kalmu had become a mystic or shaman. At 18 , he had been married to an attractive Kholi (weaver) girl of Taal village. Within two years, two children were born. "Then tragedy struck, in the form of an illness which afflicted all four members of the young family, and from which only Kalmu survived. Grief-stricken, he tried to immolate himself on his wife's funeral pyre but was prevented from doing so by bystanders. He brooded for some time thereafter, drifting aimlessly from place to place and spending considerable time in worship and meditation on other-worldly matters. Then one day, while meditating and worshipping in his father's house, and in the com- 
pany of several other people, there was a sudden commotion in the semidarkness, and a silver coin, a brass coin, and a small smooth, oblong stone (described as a "bindi" and regarded as a Shiva lingam) dropped from nowhere into a brass tray he had been holding. He then grasped a pumpkin from nearby, stood up, and as he held it over his head, an unseen being ate half of it before the onlookers' amazed eyes. Then Kalmu began to be 'played upon' or possessed by a supernatural being" (Berreman 1972, pp. 381-395; plate 33).

15. Hanumān, the Monkey God, in meditation. Hanumān (litt. "with the large jaws") as danced in Kathakali, the sacred dance-drama of Kerala. The artist is Ramankutty Nair. Hanumann belongs to a class of beings whose facial make-up is classified in the Kathakali tradition as "white beard." In addition to his white beard, he has a white $c u t t i$, made from rice paste and lime (nowadays sometimes paper), attached to his cheeks and reaching to the ends of his eyebrows. The face is painted in black, red, green, and white. The head-gear resembles a Chinese hat (cf. Bharatha Iyer 1955, p. 48; also plate XXI, figure 2). The hand gestures (mudra) for meditation displayed here are called mudrākhya. The scene comes from the beginning of the drama Kalyanna Saugandhika, derived from the epic Mahäbhärata. The actors do not speak; the story is chanted in Malayalam verse. It relates how Bhima, the great hero and Hanumān's brother, searched the jungle for a flower for his wife "like the sweetly perfumed one which a wind from Paradise had wafted to her feet." "Hanuman is seated in meditation in the forest, his eyes rolled up, his right arm raised, his left hand pointing inwards to his navel. The approach of Bhima penetrates his yogic trance; three times he stirs from it but returns again to his absorption. At last he starts into full consciousness and begins to reconstruct the scene and to picture the possible intruder" (de Zoete 1953, pp. 100-102; cf. plate 14d).-Photograph from Kerala Kalamandalam, Cheruthuruthy, through the American Society for Eastern Arts, Berkeley.

16. JÑ̃̃Na: ŚRĩ Ramaña Maharṣi at age 21. Śrī Ramaṇa Maharși $\left(1879^{-1950)}\right.$, whose original name was Venkataraman, was born in a small village in South India and went to the sacred hill of Arunaacala "the hill of dawn" when he was seventeen years old. At the foot of Arunaancala lies Tiruvannamalai, a small town with a large Siva temple and now with an äśrama called after Srì Ramana. Before he left, Venkataraman was struck by the fear of death: "I felt: 'Now I must die.'" He did not consider calling a doctor, a relative or even a stranger. "I felt that I had to solve this problem by myself, here and now, immediately." He enacted his own death: he stretched out stiff like a corpse, 
closed his eyes and held his breath. Then he said to himself: "All right, this body is dead. But am I dead? Is this body 'I'?" Ever since, Sri Ramaña Maharși asked only one question: "Who am I?" He spoke little and wrote less. His few teachings, mostly taken down by pupils and visitors, are expressed with rare intensity and directness. Though they hardly refer to the traditional scriptures, these teachings constitute the closest contemporary parallel to many passages in the Upanisads (see Zimmer 1944).-Photograph from Sri Ramanasramam, Tiruvannamalai 